
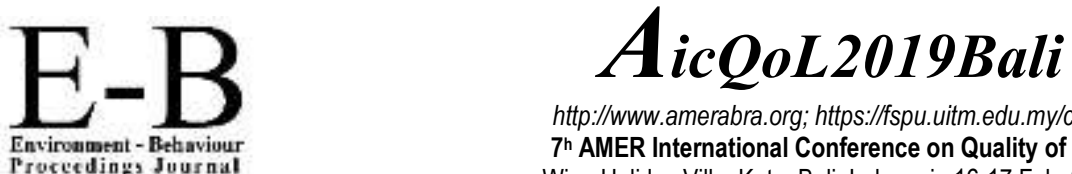

http://www.amerabra.org; $h$ ttps://fspu.uitm.edu.my/cebs $7^{\text {th }}$ AMER International Conference on Quality of Life Wina Holiday Villa, Kuta, Bali, Indonesia 16-17 Feb. 2019

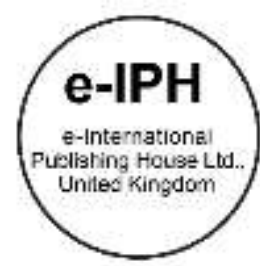

\title{
An Overview of Environmental Design Relationship with School Bullying and Future Crime
}

\author{
Azna Abdul Wahab 1, Siti Rasidah Md Sakip 2 \\ 1 Universiti Teknologi MARA, Shah Alam Campus, 40450, Selangor, Malaysia \\ 2 Department of Landscape Architecture, Faculty of Architecture, Planning \& Surveying, \\ Universiti Teknologi MARA Perak Branch, Seri Iskandar Campus, 32610, Perak, Malaysia \\ ${ }^{2}$ Green Safe Cities Research Group, \\ Universiti Teknologi MARA, Shah Alam Campus, 40450, Selangor, Malaysia \\ azna.abdulwahab@yahoo.com, sitir704@perak.uitm.edu.my \\ Tel: (+60)1116446048
}

\begin{abstract}
This article presents an overview of how environmental design is related with school bullying and future crime. Through a discussion of findings from previous studies, gaps in criminology knowledge on the bully-design link and future crime will be highlighted. Bullying is a serious social problem that can affect and impact a student's future. The previous studies had indicated the link between bullying behaviour and future crime for the bully and the victim. In conclusion, this article will emphasise the need for future research in environmental design and bullying behaviour.
\end{abstract}

Keywords: Environmental design; School bullying; Criminality; Crime

eISSN: 2398-4287 @ 2019. The Authors. Published for AMER ABRA cE-Bs by e-International Publishing House, Ltd., UK. This is an open access article under the CC BYNC-ND license (http://creativecommons.org/licenses/by-nc-nd/4.0/). Peer-review under responsibility of AMER (Association of Malaysian Environment-Behaviour Researchers), ABRA (Association of Behavioural Researchers on Asians) and CE-Bs (Centre for Environment-Behaviour Studies), Faculty of Architecture, Planning \& Surveying, Universiti Teknologi MARA, Malaysia.

DOI: https://doi.org/10.21834/e-bpj.v4i10.1631

\subsection{Introduction}

Bullying is a growing problem that affects millions of students throughout the world. Bullying among students has been known to be a severe problem in schools for almost 30 years (Roland \& Galloway, 2002). Bullying in schools reflects a part of the bigger problem of violence in society (Atlas \& Pepler, 1998). Previous longitudinal studies have found a strong and consistent relationship between bullying and later criminality (Andershed, Kerr, \& Stattin, 2001; Min, F. Catalano, P. Haggerty, \& D. Abbott, 2011; Dan Olweus, 2011; Renda, Vassallo, \& Edwards, 2011; Sourander et al., 2011). Bullying behaviour among students is a global phenomenon that not only occurs in Malaysian schools but also other countries such as Australia, Japan, England, and the United States. Past research has shown that at least 5 per cent of students in primary and secondary schools were bullied weekly or more often in North America, Australia, Japan, the Scandinavian countries and several other countries in Europe (Roland \& Galloway, 2002). The United States Department of Justice and the National Association of School Psychologists (NASP) estimate that 160,000 children miss school each day out of fear (NewmanCarlson \& Horne, 2004). In 2013, approximately 3 per cent of students aged between 12 and 18 years old reported being afraid of being attacked or harmed at school or on the way to and from school (Robers, Zhang, \& Morgan, 2015). Bullying is linked to many adverse outcomes of various important aspects of life, including student achievement, physical health, mental health, and later life. Adolescents who are bullied suffer from the worst psychological effect that can be linked to suicidal thinking. The Olweus Prevention Program was designed to prevent bullying in elementary, middle and junior high schools and was a school-based program (Losey, 2009). The program was targeted primarily at bullies and students who were victimised by bullying behaviour. Thus, the objective of this article is to overview the bullying scenario in Malaysia and the link between bullying behaviour with future crime and environmental design. In achieving the

eISSN: 2398-4287 (C) 2019. The Authors. Published for AMER ABRA cE-Bs by e-International Publishing House, Ltd., UK. This is an open access article under the CC BYNC-ND license (http://creativecommons.org/licenses/by-nc-nd/4.0/). Peer-review under responsibility of AMER (Association of Malaysian Environment-Behaviour Researchers), ABRA (Association of Behavioural Researchers on Asians) and cE-Bs (Centre for Environment-Behaviour Studies), Faculty of Architecture, Planning \& Surveying, Universiti Teknologi MARA, Malaysia.

DOI: https://doi.org/10.21834/e-bpj.v4i10.1631 
objective, 65 articles on school bullying, future crime, and school environmental design were reviewed. Students who engage in bullying may be more likely to engage in criminality in the future. The environmental design may influence bullying behaviour in school and can be used as a prevention tool for the school bullying problem in Malaysia.

\subsection{Scenario of Bullying in Malaysia}

In 2014, criminal cases of bullying in Malaysia gained great attention from the Ministry of Education (MOE), the Social Welfare Department (SWD) and the Royal Malaysian Police (RMP) when a bullying crime video was uploaded onto the internet making it viral among Malaysians. In November 2014, an orphanage dormitory became the scene of bullying-related crimes when a primary student was brutally assaulted by several secondary school students (Astro Awani, 2014). The Director-General of Education, Datuk Seri Dr. Khair Mohamad Yusof, revealed that a total of 13,359 primary and secondary school students were involved in criminal misconduct from January to June 2014. From this total number, 1,314 students were investigated under bullying cases and 4,568 under serious crimes (Salleh, 2014). According to the Vice Chairman of the Malaysian Crime Prevention Foundation (MCPF), Tan Sri Lee Lam Thye, student involvement in criminal activities formed 0.9 per cent of the total crime index in the country (Utusan Online, 2016). The Ministry of Education stated that the number of students involved in disciplinary action was less than 2 per cent of the 5 million students in Malaysia (Astro Awani, 2015). Although only 2 per cent of students are involved in disciplinary actions, nevertheless, bullying remains as a crime that causes irreversible psychological and emotional effects, or worse, death to the victims. The consequences of bullying are dire. It could be physical health and psychological consequences such as low self-esteem, anxiety, depression, physical disorder and absenteeism (Rigby, K. 2003). Bullying has an effect not only on the victims but also on the entire school community and their families and has a tremendous financial and social cost to society (Y. Kemp-Graham \& LaVelle, 2015). In order to decrease the crime rate, The National Key Results Area (NKRAs) under the Government Transformation Program (GTP) was implemented in 2010, and one of the seven NKRAs is Reducing Crime NKRA (CRI NKRA). It is one of the Government's efforts to decrease the crime rate as the crime was indicated to be the second largest area of concern for society after the economy.

Based on the violent crime statistical data from the Royal Malaysia Police (RMP) regarding violent crime cases involving children between the ages 7 to 18 years, the analysis of violent crimes between 2010 and Sept 2015 is shown in Figure 1 below. The six-year (2010- Sept 2015) archival analysis shows that a total of 2,946 violent crime cases involving children between the ages of 7 to 18 years were recorded throughout Malaysia.

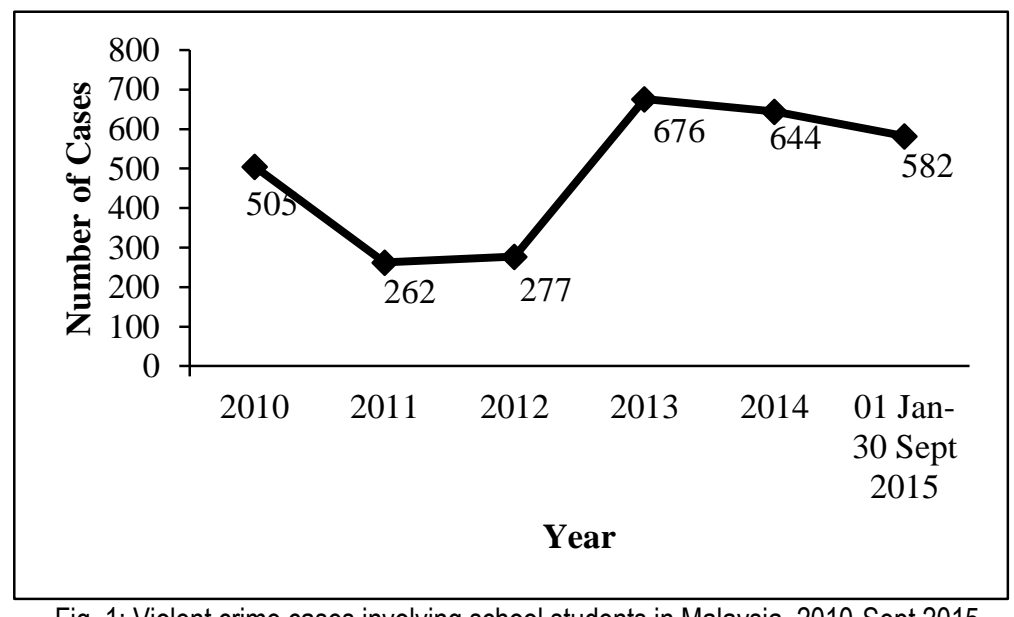

Fig. 1: Violent crime cases involving school students in Malaysia, 2010-Sept 2015 (Source: RMP, 2015)

The highest number of cases involving students was recorded in 2013 ( 676 cases) followed by 2014 ( 644 cases). The crime numbers decreased from 505 cases in 2010 to 262 cases in 2011 (a decline of 243 cases or 48.12 per cent). The recorded number of violent crime cases increased slightly from 2011 to 2013 (414 cases or 158.02 per cent) and steadily decreased in 2014 and 2015. However, it must be noted that some of the cases went unreported and the record for 2015 is only up to September. Thus, the number of crimes involving students in 2015 can be estimated to be much higher than recorded. An anti-bullying act has yet to be enacted in Malaysia. Bullying suspects are mostly charged under harassment under the Penal Code that acts as a general law on criminal offences in Malaysia.

\subsection{Bullying Behavior}

Bullying can be defined as negative actions that repeatedly occur over time directed against another student who has difficulty in defending himself or herself (D Olweus, n.d.; Wan Ismail et al., 2010). Negative actions refer to behaviour that is intended to inflict harm, injury, pain, or discomfort upon another individual (Atlas \& Pepler, 1998). Meanwhile, Atlas \& Pepler (1998) defined bullying as a form of social interaction in which there is an implied imbalance of power or strength in the interaction. The power imbalance in bullying may not be limited to physical size and may be presented in the tone of voice, the physical stance of the bully, or the number of children 
taking part as bullies and the support of involved peers (Atlas \& Pepler, 1998). Hence, bullying will take place when there is an imbalance of power between people with negative action and those who have difficulty to defend themselves.

The common form of bullying can be categorised into two types; direct and indirect (Yerger \& Gehret, 2011). Direct bullying behaviours involve behaviours that are observable and that are usually expressed by physical and verbal means. Usually, direct bullying involves relatively open attacks on a victim and is "in front of your face" behaviours. The most violent forms of this bullying may lead to death. Indirect bullying is intended to hurt victims by damaging their self-esteem or social relationships, through behaviours such as exclusion from a group, rumour-mongering, and giving nasty looks (Dedousis-Wallace \& Shute, 2009). There have been more cases of direct bullying than indirect physical bullying (Atlas \& Pepler, 1998). Verbal bullying has been found to be the most widely performed type of bullying (Boulton, Trueman, \& Flemington, 2002; Mohamad Salleh \& Zainal, 2014; K Rigby, 2008) that can be done quietly and covertly where the children are able to avoid detection and punishment (Atlas \& Pepler, 1998). A strong association between bullying and suicide has been indicated for indirect bullying compared to direct bullying (F. van der Wal, A. M. de Wit, \& A. Hirasing, 2003). Boys and girls are equally likely to bully which means there are no gender differences in bullying (Atlas \& Pepler, 1998). Meanwhile, in-class observation, victims of bullying were frequently boys rather than girls (Atlas \& Pepler, 1998). Based on the research by Atlas and Pepler (1998), bullying happened as much as twice every hour in the class for short durations.

\subsection{Factors Contributing to Bullying}

Factors associated with bullying among young adolescents are sociodemographic, psychological, (Wan Ismail, Nik Jaafar, Sidi, Midin, \& Shah, 2014), social environmental factors (Bowes et al., 2009; Roland \& Galloway, 2002; Stevens, Bourdeaudhuij, \& Oost, 2002; Vidourek, King, \& Merianos, 2016), and physical environmental factors (Johnson, 2009; Wilcox, Augustine, \& Clayton, 2006). The majority of bullies are adolescent males who come from a lower socioeconomic standing (Wan Ismail et al., 2014) that indicated more exposure to community violence (J. Osofsky, 1997). It was observed that social environmental factors, such as peers, the school (Bowes et al., 2009; Vidourek et al., 2016) , the classroom (Roland \& Galloway, 2002), the neighborhood (Bowes et al., 2009) and home environment (Bowes et al., 2009; Stevens et al., 2002), contributed to the risk of bullying behavior at school. School size was associated with being the victim of bullying as teachers may be less aware of children's social behaviours and have difficulties in supervising children out of lesson time (Bowes et al., 2009). Meanwhile, schools that contradictorily impose rules against bullying accept student bullying and has low levels of adult supervision have higher rates of bullying (Vidourek et al., 2016). Hostile interaction in the neighbourhood showed children the examples of bullying behaviours that they can imitate among their peers (Bowes et al., 2009). Family background plays a vital role in influencing bullying behaviour as the early approach is received from the family. Students involved in bullying were more likely to have been exposed to low-income family management and antisocial peers (Min et al., 2011; Roland \& Galloway, 2002). Family conditions may be related to social conditions in class and may thus have an indirect impact on bullying (Roland \& Galloway, 2002). The use of violence and extreme action as a method to discipline the children by parents, guardians, and teachers can indirectly promote violent acts among children (Bowes et al., 2009; Stevens et al., 2002). However, findings from Roland and Galloway (2002) indicated that there is no significant connection between the family condition and bullying other students. Their results may have varied from the other researchers because the data was collected when the schools were about to finish the school year and the respondents were excited about the end of school. The violent acts that are often aired on television and films influence children and adolescents to behave violently in imitation (Verlinden et al., 2014; Wan Ismail et al., 2014). Exposure to violence can have significant effects on children's development (J. D. Osofsky, 1999). Roland \& Galloway (2002) argue that differences in social condition at school and classroom level could be attributed to parallel differences in the home conditions of the students. Bullying behaviour is also attributable to the individual's personality style (D. P. Farrington \& Ttofi, 2011; Mohamad Salleh \& Zainal, 2014). A student's personality such as ego, irritability, revenge, and fun can influence the behaviour of bullies (Mohamad Salleh \& Zainal, 2014). Wilcox et al. (2006) conducted an entire study on the school environment and its relationship with school crime. Wilcox et al. (2006) focused on school design, noting that improved territoriality indicated school ownership, and improved surveillance led to a better perception of safety in school.

\subsection{Consequences of Bullying}

The effects related to student bullying are numerous in terms of individual, interpersonal and social adjustment issues (Rigby, K. 2003). The bullying may have an impact on the learning process for bullies, victims and peers (Atlas \& Pepler, 1998) while the effect on the victims is mostly associated with poor academic performance (Nakamoto \& Schwartz, 2010). This type of violence may result in various physical, psychological, and social adjustment, as well as academic challenges, leading to distress on the overall well-being (Rigby, K. 2003) and quality of life of these victimised adolescents (Gladden, Vivolo-Kantor, Hamburger, \& Lumpkin, 2014). Psychological distress is considered a serious problem among the victims which include high levels of anxiety, depression, (Hawker \& Boulton, 2000; Nakamoto \& Schwartz, 2010; Reijntjes, Kamphuis, Prinzie, \& Telch, 2010; Rigby, K., 2003) and suicidal thinking (Rigby, K., 2003; Sourander et al., 2011). Students who were frequently bullied were significantly more likely than others to experience trauma (Carney, 2008) and high levels of depression which can lead to suicidal ideation or may commit suicide (Carney, 2008; Klomek, Sourander, \& Gould, 2010; Rigby, K., 2003). Cross-sectional findings and a few longitudinal findings indicate that there is an increased risk of suicidal ideation and suicide attempts associated with bullying behaviour (F. van der Wal et al., 2003; Kim, Leventhal, Koh, \& Boyce, 2009; Klomek et al., 2010). Victims of bullying tend to fear to be at the school and display avoidance behaviour (Barrett, Jennings, \& Lynch, 2012; Noaks \& Noaks, 2000; Vidourek et al., 2016) due to feeling unsafe in school (Hughes, Gaines, \& Pryor, 2014; Safran, 2008). Numerous studies 
have indicated that being bullied is positively associated with being frequently absent and having the lower academic achievement (Barrett et al., 2012; Gastic, 2008; Goldammer, 2011; Hughes et al., 2014; Noaks \& Noaks, 2000; Vidourek et al., 2016).

\subsection{Bullying Prevention}

The school-based intervention program by Olweus (1978) was the first bullying intervention and reduction program to be evaluated by systematic research. After two years of intervention in the school, classroom environment, and through the students, teachers and parents, the frequency of bullying problems in schools decreased by approximately 50 per cent (D Olweus, n.d.). Improving the social learning environment (SLE) factor by monitoring student behaviour outside the classroom, the interaction between the teachers and collaboration between the school's stakeholders are important steps to reduce bullying in school (Kyriakides, Creemers, Papastylianou, \& Papadatou-pastou, 2014). Apart from monitoring student behaviour outside the classroom, schools also can organise activities during recess which can calm students' aggressiveness and increase students' feelings of safety, happiness, and liking of school (Swearer, Espelage, \& Napolitno, 2009). These methods can influence high-quality peer communication and togetherness with one another that can be defined as a responsive school environment.

\subsection{The Relationship Between Bullying Behavior and Future Crime}

Being witness to or being involved in direct contact with school victimisation may be related to a youth's criminal activity in the future ( $\mathrm{J}$. D. Osofsky, 1999). Previous longitudinal studies have found a strong and consistent relationship between bullying and later criminality (Andershed et al., 2001; Min et al., 2011; Dan Olweus, 2011; Renda et al., 2011; Sourander et al., 2011). Adolescents who bully others have been found to be at heightened risk of engaging in later anti-social and criminal behaviour (D. Farrington, 1993; Sourander et al., 2007) and in fact are more likely to engage in concurrent criminal activity during adolescence (Jiang, Walsh, \& K. Augimeri, 2011; Nixon, 2015). The probability for bullies to engage in crime is much higher than non-bullies. The bullies reported significantly higher incidence rates (3.39 per 100 person-years) compared with the non-bullies (1.17 per 100 person-years) (Jiang et al., 2011). D. P. Farrington and Ttofi (2011) reported that 40.8 per cent of 71 bullies were convicted of crimes between the ages of 15 and 20, compared with 24.8 per cent of 331 non-bullies. Andershed et al. (2001) argued that bullying is a reflection of an individuals' characteristic ways of interacting with others. Findings from Andershed et al. (2001) indicated that bullying behaviour in schools is related strongly to violent behaviour and loitering on the streets among boys and girls. Thus, it may be expected that an adolescent who bullies in school is considerably more violent on the streets. The linkage between childhood bullying behaviour and future offending is strong after the age of 12 (Jiang et al., 2011). 24 from 260 bullies had at least one official criminal conviction before the age of 18 (Jiang et al., 2011). Renda et al. (2011) found that bullying at age 13-14 years has a significantly stronger association with anti-social behaviour at ages 19-20 than at ages 2324. Supported findings by Dan Olweus (2011) indicated that from the total of 278 bullies considered, 55 per cent of them had been convicted of one or more crimes and as much as 36 per cent had been convicted of at least three crimes in the eight-year period from ages 16 to 24. However, Sourander et al. (2011) found that bullying at age eight is also a strong predictor of adult criminality among males, but does not predict adult criminality among females. Min et al. (2011) concluded that childhood bullying is significantly associated with violence, heavy drinking, and marijuana use at age 21. Renda et al. (2011) suggested that bullying in adolescence may be a marker of risk for a continuing pattern of anti-social behaviour, particularly among boys. However, a study by D. P. Farrington \& Ttofi (2011) presented evidence for bullying at age 14 as a predictor for violent convictions between ages $15-20$, self-reported violence at ages 15 18 , low job status at age 18, drug use at ages $27-32$, and an unsuccessful life at age 48.

\subsection{The Relationship Between Environmental Design and Bullying Behavior}

The basis of environmental design is the interaction among the physical, social, environmental, individual, and community factors (Sakip, Johari, \& Salleh, 2012). According to Poyner (1983), human movement and behaviour are critically affected by the design and layout of the physical environment. Architectural design and layout of buildings, street networks and so on can significantly influence how people interact, use, and move in their environment (Reynald, 2014). Crimes are believed to be related to the physical environment (Liebermann \& Kruger, 2004). The opportunities that exist in an environment encourage a criminal to act on a targeted victim (Liebermann \& Kruger, 2004). In deciding whether or not to commit an act of crime, the environmental element is one of the factors considered by criminals (Anastasia \& John, 2007). Criminal behaviour is driven by their environment, whether physical or social aspect (Sakip \& Abdullah, 2008). A study by Shamsuddin et al. (2012) had indicated a relationship between the outdoor physical environment of the school and the students' social behaviour. However, the limitation of this research is not evaluating the negative social behaviour related to a school's environment. A study of school violence in the Gangseo district, Seoul was conducted to determine crime spots on the way home from school for middle-school students (Lee, Ryu, \& Ha, 2012). Through a cognitive map analysis, Lee, Ryu, and Ha (2012) argued that the students feel fear mostly for reasons related to human factors rather than to space factors; among the human factors, 'peers' represented the most common reason. The most common locations for student victimization are at the playground (Fite et al., 2013; Dan Olweus, 1993; Stephenson \& Smith, 1989), classroom (Atlas \& Pepler, 1998; Rapp-paglicci, Dulmus, Sowers, \& Theriot, 2004), and hallways (Astor, Meyer, \& Behre, 1999; Stephenson \& Smith, 1989; Vidourek et al., 2016). Certain 'hot spots' indicated to be unowned spaces were the sites of more crime events and induced greater fear among students (Astor et al., 1999). The presence of a sense of ownership of these locations has the potential to drastically decrease the prevalence of victimisation in schools (Astor et al., 1999). These studies show that victimisation is most likely to occur when the adults are limited in their ability to monitor. The school structure may play an important part in giving a chance for individual children to be involved in bullying behaviour (Atlas \& Pepler, 1998). Craig et al. (2000) 
reported that victimisation is most likely to occur in less structured environments. Studies showed that lower rates of school victimisation were associated with school safety interventions that are focused on improving the physical environment of the school (Johnson, 2009). Johnson (2009) concluded that the physical environment appears to offer intervention opportunities to reduce school victimisation.

\subsection{Discussion}

School bullying is a serious problem experienced by all schools that could have an impact on students' physical and psychological wellbeing. School bullying can be categorised into two types, which are direct bullying and indirect bullying. Direct bullying is an action that happens face to face between the bully and the victim. Meanwhile, indirect bullying is an action that discriminates another student by spreading rumours that will damage the victim's social relationships. Even though physical injuries caused by direct bullying is seen to be the worst impact on the victims, the psychological impact caused by indirect bullying should not be ignored. Students who suffer indirect bullying will experience psychological stress which includes high levels of anxiety, depression and suicidal thoughts. A male student is more likely to bully other students compared to a female student. The factors that contribute to school bullying are sociodemographic, psychological, social environmental and physical environmental factors. The majority of bullies come from a lower socioeconomic group that indicated more exposure to community violence and hostile interaction. An individual's personality such as ego, irritability, revenge, and fun can influence the behaviour of bullies. Social environmental factors such as peers, school, classroom, neighbourhood and home environment contribute to the risk of bullying behaviour at school. A low-income family management prone to using violence and extreme action as disciplinary methods can indirectly promote violent acts among children. Under these circumstances, children tend to believe that action against others is a way for them to solve problems. The victims of bullies tend to be fearful at school and have an avoidance behaviour. They are likely to be absent from school and have low academic achievement. Thus, they would have low job status in the future. Students who were involved in bullying at age eight either as the perpetrators or as victims are at heightened risk of engaging in later anti-social and criminal behaviour. In fact, they are more likely to engage in concurrent criminal activity during adolescence. The adolescent who bullies in school is considerably more violent on the streets. Steps taken in bullying prevention today are mostly derived from the Olweus Bullying Prevention Program that emphasised on school, classroom environment, students, teachers and parents. However, cases of bullying still occur. Bullying may be preventable through environmental design. The most common locations for bullying are at the playground, classroom, and school hallways. Bullies tend to choose places that have narrow spaces, are invisible to other people and indicated to be unowned spaces. The presence of a sense of ownership in that place could reduce the opportunities for offending by discouraging illegitimate users (Cozens, Saville, \& Hillier, 2005; Perkins, Meeks, \& Taylor, 1992). Thus, the environmental design could influence the bullying behaviour since most of the cases occurred at hidden places without good surveillance and unused space that provided opportunities for bullying. For future research, the researcher recommends a further study on how environmental design influences bullying behaviour and whether environmental design can be used as a prevention tool for the problem of school bullying.

\section{Acknowledgements}

The researchers would like to thank the Royal Malaysian Police (PDRM), and the Malaysian Ministry of Higher Education for supporting this research via the Fundamental Research Grant Scheme (FRGS) of (FRGS/1/2015/SSI11/UITM/02/12).

\section{References}

Anastasia, L., \& John, E. (2007). Crime prevention and active living. American Journal of Health Promotion.

Andershed, H., Kerr, M., \& Stattin, H. (2001). Bullying in School and Violence on the Streets: Are the Same People Involved? Journal of Scandinavian Studies in Criminology and Crime Prevention, 2(1), 31-49.

Astor, R. A., Meyer, H. A., \& Behre, W. J. (1999). Unowned Places and Times: Maps and Interviews About Violence in High Schools. American Education Research Journal, 36(1), 3-42.

Astro Awani. (2014). Video Buli Pelajar Berlaku Di Asrama Anak Yatim Di Perlis.

Astro Awani. (2015). Kes buli semakin serius harus dipandang serius semua pihak - Lee Lam Thye.

Atlas, R. S., \& Pepler, D. J. (1998). Observations of Bullying in the Classroom. Journal of Educational Research, 92(2), 86-99.

Barrett, K. L., Jennings, W. G., \& Lynch, M. J. (2012). The Relation Between Youth Fear and Avoidance of Crime in School and Academic Experiences. Journal of School Violence, 11(1), 1-20.

Boulton, M. J., Trueman, M., \& Flemington, I. (2002). Associations between Secondary School Pupils' Definitions of Bullying, Attitudes towards Bullying, and Tendencies to Engage in Bullying: Age and sex differences. Educational Studies, 28(January 2015), 353-370.

Bowes, L., Arseneault, L., Maughan, B., Taylor, A., Caspi, A., \& Moffitt, T. E. (2009). School, neighborhood, and family factors are associated with children's bullying involvement: a nationally representative longitudinal study. Journal of the American Academy of Child and Adolescent Psychiatry, 48(5), 545-53. 
Brunstein Klomek, a, Sourander, A., \& Gould, M. (2010). The Association of Suicide and Bullying in Childhood Longitudinal Research Findings. Canadian Journal of Psychiatry, 55(5), 282-288.

Carney, J. V. (2008). Perceptions of Bullying and Associated Trauma during Adolescence. Professional School Counseling, 11(3), 179-188.

Cozens, P., Saville, G., \& Hillier, D. (2005). Crime prevention through environmental design (CPTED): a review and modern bibliography. Property Management.

Craig, W. M., Pepler, D. J., \& Atlas, R. (2000). Observation of Bullying in the Playground and in the Classroom. School Psychology International, 21(1), 22-36.

Dedousis-Wallace, A., \& H. Shute, R. (2009). Indirect Bullying: Predictors of Teacher Intervention, and Outcome of a Pilot Educational Presentation about Impact on Adolescent Mental Health. Australian Journal of Educational \& Developmental Psychology, 9, 2-17.

F. van der Wal, M., A. M. de Wit, C., \& A. Hirasing, R. (2003). Psychosocial Health Among Young Victims and Offenders of Direct and Indirect Bullying. Pediatrics, 111(6), 1312-1317.

Farrington, D. (1993). Understanding and preventing bullying. Crime and Justice.

Farrington, D. P., \& Ttofi, M. M. (2011). Bullying as a predictor of offending, violence and later life outcomes. Criminal Behaviour and Mental Health: CBMH, 21(2), 90-8.

Fite, P. J., Williford, A., Cooley, J. L., DePaolis, K., Rubens, S. L., \& Vernberg, E. M. (2013). Patterns of Victimization Locations in Elementary School Children: Effects of Grade Level and Gender. Child and Youth Care Forum, 42(6), 585-597.

Gastic, B. (2008). School truancy and the disciplinary problems of bullying victims. Educational Review, 60(4), 391-404.

Gladden, R. M., Vivolo-Kantor, A. M., Hamburger, M. E., \& Lumpkin, C. D. (2014). Bullying surveillance among youths: Uniform definitions for public health and recommended data elements, Version 1.0. Centers for Disease Control and Prevention Atlanta, Georgia, 4-101.

Goldammer, L. (2011). Bullying in Georgia Schools: Demographic Profiles and Psychosocial Correlates of Students Who Would Intervene in a Bullying Situation.

Harian Metro. (2014). 1,314 Murid Terbabit Buli. Harian Metro.

Hawker, D., \& Boulton, M. (2000). Twenty years' research on peer victimization and psychosocial maladjustment: a meta-analytic review of cross-sectional studies. Journal of Child Psychology and.

Hughes, M. R., Gaines, J. S., \& Pryor, D. W. (2014). Staying Away From School: Adolescents Who Miss School Due to Feeling Unsafe. Youth Violence and Juvenile Justice, 13(3), 270-290.

Ismail, W. S. W., Jaafar, N. R. N., Sidi, H., Midin, M., \& Shah, S. A. (2014). Why do young adolescents bully? Experience in Malaysian schools. Comprehensive Psychiatry, 55, S114-S120.

Jiang, D., Walsh, M., \& K. Augimeri, L. (2011). The linkage between childhood bullying behaviour and future offending. Criminal Behaviour and Mental Health, 21, 128135.

Johnson, S. L. (2009). Improving the school environment to reduce school violence: a review of the literature. Journal of School Health, 79(10), 451-465 15p.

Kim, Y. S., Leventhal, B. L., Koh, Y.-J., \& Boyce, W. T. (2009). Bullying increased suicide risk: prospective study of Korean adolescents. Archives of Suicide Research: Official Journal of the International Academy for Suicide Research, 13(1), 15-30.

Kyriakides, L., Creemers, B. P. M., Papastylianou, D., \& Papadatou-pastou, M. (2014). Improving the School Learning Environment to Reduce Bullying: An Experimental Study, 3831(December 2015).

Lee, S., Ryu, H., \& Ha, M. (2012). Criminal Spots on the Way Home from School a Case Study of Middle Schools in the Gangseo District, (May), 63-70.

Liebermann, S., \& Kruger, T. (2004). Crime Prevention Through Environmental Design (CPTED). In 9th International Conference on Crime Prevention Environmental Design.

Losey, R. A. (2009). An Evaluation of the Olweus Bullying Prevention Program's Effectiveness in a High School Setting.

Min, J. K., F. Catalano, R., P. Haggerty, K., \& D. Abbott, R. (2011). Bullying at elementary school and problem behaviour in young adulthood: A study of bullying, violence and substance use from age 11 to age 21. Criminal Behaviour and Mental Health, 21, 136-144.

Nakamoto, J., \& Schwartz, D. (2010). Is Peer Victimization Associated with Academic Achievement? A Meta-Analytic Review. Social Development, 19(2), $221-242$.

Newman-Carlson, D., M, \& Horne, A. (2004). Bully Busters: A Psychoeducational Intervention for Reducing Bullying in Middle School Students. Journal of Counseling \& Development, 82, 259-267.

Nixon, T. C. (2015). Relationship Between Bullying Experiences and Criminality: Bullies, Bully Victims, Victims, and Witnesses.

Noaks, J., \& Noaks, L. (2000). Violence in School: Risk, safety and fear of crime. Educational Psychology in Practice, 16(1), 69-73.

Olweus, D. (1978). Aggression in the schools: Bullies and whipping boys.

Olweus, D. (1993). Bullies on the playground: The role of victimization. In Children on Playgrounds: Research Perspectives and Applications (pp. 85-128). SUNY Press.

Olweus, D. (1993). Victimization by peers: Antecedents and long-term outcomes. Social withdrawal, inhibition, and shyness in childhood. 
Olweus, D. (2011). Bullying at school and later criminality: Findings from three Swedish community samples of males, 156, 151-156.

Osofsky, J. (1997). Children in a violent society.

Osofsky, J. D. (1999). The impact of violence on children. Future of Children, 9(3), 33-49.

Perkins, D., Meeks, J., \& Taylor, R. (1992). The physical environment of street blocks and resident perceptions of crime and disorder: Implications for theory and measurement. Journal of Environmental Psychology.

Poyner, B. (1983). Design against crime: Beyond defensible space.

Rapp-paglicci, L., Dulmus, C. N., Sowers, K. M., \& Theriot, M. T. (2004). "Hotspots" for Bullying. Journal of Evidence-Based Social Work ISSN: 1(2-3), $131-141$.

Reijntjes, A., Kamphuis, J., Prinzie, P., \& Telch, M. (2010). Peer victimization and internalizing problems in children: A meta-analysis of longitudinal studies. Child Abuse \& Neglect.

Renda, J., Vassallo, S., \& Edwards, B. (2011). Bullying in early adolescence and its association with anti-social behaviour, criminality and violence 6 and 10 years later. Criminal Behaviour and Mental Health, 21, 117-127.

Reynald, D. M. (2014). Environmental Design and Crime Events. Journal of Contemporary Criminal Justice, 31(1), 71-89.

Rigby, K. (2003). Consequences of bullying in schools. Canadian Journal of Psychiatry. Revue Canadienne de Psychiatrie, 48(9), 583-90.

Rigby, K. (2008). Children and bullying: How parents and educators can reduce bullying at school.

Robers, S., Zhang, A., \& Morgan, R. E. (2015). Indicators of School Crime and Safety: 2014. NCES 2015-072/NCJ 248036. National Center for Education Statistics, (July), 248036.

Roland, E., \& Galloway, D. (2002). Classroom influences on bullying. Education Research, 44(3), $299-312$.

Safran, E. R. (2008). Bullying Behavior, Bully Prevention Programs, and Gender. Journal of Emotional Abuse, 7(4), $43-67$.

Sakip, S. R. M., \& Abdullah, A. (2008). Jenayah dan persekitaran: hubungan dan perkaitannya.

Sakip, S. R. M., Johari, N., \& Salleh, M. N. M. (2012). The Relationship between Crime Prevention through Environmental Design and Fear of Crime. Procedia - Social and Behavioral Sciences, 68, 628-636.

Salleh, N. M., \& Zainal, K. (2014). Bullying Among Secondary School Students in Malaysia: A Case Study, 7(13), $184-191$.

Shamsuddin, S., Bahauddin, H., \& Aziz, N. A. (2012). Relationship between the Outdoor Physical Environment and Student's Social Behaviour in Urban Secondary School. Procedia - Social and Behavioral Sciences, 50(July), 148-160.

Sourander, A., Brunstein Klomek, A., Kumpulainen, K., Puustjarvi, A., Elonheimo, H., Ristkari, T., ... Ronning, J. A. (2011). Bullying at age eight and criminality in adulthood: Findings from the Finnish nationwide 1981 Birth cohort study. Social Psychiatry and Psychiatric Epidemiology, 46(12), 1211-1219.

Sourander, A., Jensen, P., Rönning, J. A., Elonheimo, H., Niemelä, S., Helenius, H., ... Almqvist, F. (2007). Childhood bullies and victims and their risk of criminality in late adolescence: The Finnish from a Boy to a Man study. Archives of Pediatrics \& Adolescent Medicine, 161(6), 546-52.

Stephenson, P., \& Smith, D. (1989). Bullying in the junior school. Bullying in Schools.

Stevens, V., Bourdeaudhuij, I. De, \& Oost, P. Van. (2002). Relationship of the family environment to Children's involvement in bully/victim problems at school. Journal of Youth and Adolescence, 31(6), 419-428.

Swearer, S. M., Espelage, D. L., \& Napolitno, S. A. (2009). Bullying prevention and intervention: Realistic strategies for schools.

Utusan Online. (2016). Pihak berwajib perlu tangani masalah keganasan. Retrieved March 31, 2016, from http://www.utusan.com.my/berita/jenayah/pihak-berwajib-perlutangani-masalah-keganasan-1.205605

Verlinden, M., Tiemeier, H., Veenstra, R., Mieloo, C. L., Jansen, W., Jaddoe, V. W., ... Jansen, P. W. (2014). Television viewing through ages 2-5 years and bullying involvement in early elementary school. BMC Public Health, 14, 157.

Vidourek, R. A., King, K. A., \& Merianos, A. L. (2016). School bullying and student trauma: Fear and avoidance associated with victimization. Journal of Prevention \& Intervention in the Community, 44(2), 121-129.

Wi, W. S., Tan, S. M. K., Nj, N. R., Iryani, T., Syamsul, S., Aniza, A., \& Zasmani, S. (2009). School Bullying Among Standard Six Students Attending Primary National Schools in The Federal Territory Oo Kuala Lumpur: The Prevalence and Associated Socio-Demographic Factors, 1-8.

Wilcox, P., Augustine, M. C., \& Clayton, R. R. (2006). Physical environment and crime and misconduct in Kentucky schools. Journal of Primary Prevention, 27(3), 293313.

Y. Kemp-Graham, K., \& LaVelle, H. (2015). The Socio-Emotional and Financial Costs of Bullying. Journal of Bullying and Social Aggression, 1(1).

Yerger, W., \& Gehret, C. (2011). Schools Understanding and Dealing With Bullying in Schools. The Educational Forum, 75(4), 315-326. 